\title{
Ash Yellows in Zion National Park: Impact, Identity of Pathogen Mode of Spread, and Prospects for Management
}

\author{
WAYNe A. SinClair \\ Department of Plant Pathology \\ CORNELL UNIVERSITY \\ ITHACA, NY
}

\author{
Michael TRESHOW \\ DEPARTMENT OF BIOLOGY \ UNIVERSITY OF UTAH \\ Salt Lake City, UT
}

ROBERT E. DAVIS

Microbiology and Plant Pathology Laboratory $\downarrow$ ARS, USDA, Plant Science Institute

BeLtSVILLE, MD

\section{Problem Description and Project Objectives}

\section{$\downarrow$ THE PROBLEM}

Many velvet ash (Fraxinus velutina) in Zion Canyon have declined in vigor, and some are dying. This species is aesthetically and ecologically important in the canyon, because it is one of only three species that commonly grow to large size on the canyon floor. None of the three species is reproducing abundantly, because suitable seedbeds are scarce and young plants are severely browsed by deer. A disease known as ash yellows, which is caused by unnamed mycoplasmalike organisms (wall-less, obligately parasitic prokaryotic organisms, commonly called MLOs) was found in Zion Canyon in 1988, and is suspected to cause or contribute to the decline of velvet ash there. Until this project began, nothing was known about the ecology or epidemiology of ash yellows in the West.

\section{Research Objectives}

1. Determine the extent of damage to ash species in Zion Park, and map distribution of ash yellows in the park.
2. Learn whether or not the MLOs in ash species in Zion Park are closely related to those associated with ash yellows in Nevada and New York.

3. Determine the means and rate of spread of ash yellows and the rate at which the epidemic is progressing within the currently affected area.

4. Assess possibilities for managing the disease.

\section{Activities During The Period OF REPORT}

Project personnel visited Zion Park three times, in May, August, and October, 1990 to:

1. perform disease surveys,

2. establish observation plots,

3. perform diagnostic observations,

4. collect plant specimens for diagnostic procedures that would be performed in the laboratory, 
5. collect increment cores for study of ash growth as related to disease, and

6. collect insects for study of their possible role as vectors of ash yellows.

Increment cores and related specimens are being processed in the laboratory of co-investigator Treshow at Salt Lake City. Other specimens are or have been processed and examined in the laboratory of principal investigator Sinclair at Ithaca, NY.

\section{SURVEY FOR ASH DECLINE IN Zion National Park AND}

\section{ADJACENT AREAS}

All highways in and near the park and all trails near the floor of Zion Canyon were traversed to learn where velvet ash grows and where it is declining. Within the park, velvet ash is concentrated in Zion Canyon, and the decline syndrome (slow growth, dieback) was found to be restricted to that canyon. In areas near the park (Cedar City, Hurricane, Kanab, La Verkin, Rockville, Toquerville, Virgin, and St. George, UT), most velvet ash appeared normal. The few trees observed with dieback were on private land, had been damaged by livestock, and were not studied.

\section{$\checkmark \quad$ AsSOCiation OF MYCOPLASMal INFECTION WITH DECLINE OF VELVET ASH IN ZiON CANYON}

\section{$\downarrow \quad$ MethodS}

Sixteen sites between the south edge of the village of Springdale and The Narrows, a distance of approximately $12 \mathrm{~km}$, were selected for observations of velvet ash and associated plant species. Five or more velvet ash representing the range of health and debilitation of this species on each site were tagged and/or their locations plotted on maps, so they could be located again. Each tree was scored in one of five health categories, wherein $1=$ normal, in appearance and vigor; 2 = growing slowly, and/or having a thin crown; 3 = growing slowly, and having a thin crown and some dieback; 4 = showing much dieback; and $5=$ dead to near ground level. Sample trees were also examined for witches'-brooms (which are diagnostic for ash yellows), sprouts on the butt or bole, simple versus compound leaves on sprouts(simple-leaved sprouts are indicative of ash yellows), deliquescent branching (another indicative symptom), chlorosis, and evidence of injury by insects. Health score was later evaluated in relation to results of the DAPI fluorescence test for MLO infection.

Root samples for diagnosis by means of the DAPI fluorescence test were collected from 174 velvet ash on the 16 sites. One small root from each tree was held on ice for up to $10 \mathrm{hr}$, washed, and subsampled. Segments 2-6 $\mathrm{mm}$ in diameter were fixed and stored in $2.5 \%$ aqueous glutaraldehyde for up to 1 month. Longitudinal sections were then cut with a freezing microtome, treated with DAPI, and examined with a fluorescence microscope for MLO infection.

The condition of tree species associated with velvet ash on each site was also assessed. Root samples for assessment of possible MLO infection were collected from certain distressed trees. Ten sites and the areas surrounding them were searched for plants, other than ash, showing symptoms indicative of infection by MLOs: dwarfing, sterility, or growth forms resembling witches'-brooms. Samples for the DAPI test were collected from all such plants. The sites for this search were selected after ash yellows was diagnosed on each of them.

Singleleaf ash (Fraxinus anomala) on seven sites in Zion Canyon were selected for diagnostic observations and root sampling for possible MLO detection. The objective was to learn whether this species is affected by MLOs. Therefore, the selection of trees for sampling was deliberately biased toward stressed trees, in order to maximize the possibility of detecting MLOs.

\section{$\downarrow \quad$ Results and Discussion}

Symptoms of stress in velvet ash (slow growth, dieback, deliquescent branching) were common throughout Zion Canyon, including all research sites. Vigorous trees, as judged on the basis of either twig growth in recent years, or canopy density, were rare. Except for an occasional irrigated specimen, vigorous trees were confined to the sapling category.

Although velvet ash generally colonizes only moist sites, it was found on a number of dry sites in the lower half of the canyon, where it had become established in irrigated soil or on sand bars that were later isolated from the river. Slow growth and dieback were prominent in this species on once-irrigated sites where water supply had not been maintained. On deep sands, apparently high above the present water table, slow growth and dieback were common not only in 
velvet ash, but also in Fremont cottonwood (Populus fremontii) and boxelder (Acer negundo). We concluded that water shortage is playing a part in the decline of velvet ash in the lower half of the canyon.

Damage to all three major tree species by defoliating insects: loopers (Lepidoptera: Geometridae) and perhaps a noctuid moth (Lepidoptera: Noctuidae), and to ash by two species of plant bugs (Hemiptera: Miridae), was prominent in the upper half of the canyon. Many velvet ash and boxelder were found leafless in May, having apparently been defoliated by loopers. These insects could not be identified to species on the basis of larval characters; adults were not available. The trees had refoliated by August. Ash plant-bugs (Tropidosteptes pacificus and a species not yet identified) were responsible for stunting and distortion of young foliage and for dramatic yellowing of fully expanded foliage on some velvet ash. We judged that the insect damage was common enough and severe enough to exert a major impact on ash growth and perhaps to induce some of the observed dieback.

MLOs were detected, by means of the DAPI test, in velvet ash on 13 sites located throughout Zion Canyon and on one site each in the side canyons of Pine Creek and Oak Creek. Of 174 representative trees sampled, $66(38 \%)$ were scored positive in the DAPI test (i.e., had fluorescent particles in sieve tubes of DAPI-treated sections examined under UV). The sampled trees included 58 saplings, of which $18(31 \%)$ were scored positive. Thus, velvet ash of all ages and sizes above the reproduction class are infected. Velvet ash in the reproduction class (up to $1.4 \mathrm{~m}$ tall) are not numerous in Zion Canyon, and were not sampled extensively enough to justify a statement about MLO infection in this class. Five seedlings of atypical form (all having been browsed) were examined, and all were scored negative in the DAPI test.

The health scores of velvet ash were not significantly related to results of the DAPI test (Table 1). Three of 15 trees judged to be healthy and vigorous were found to be infected with MLOs. In all other health categories, the frequency of infected individuals was near the overall proportion of $38 \%$ infected. Differences in proportions of trees found infected in the various health classes were tested by Chi-square analysis. A proportion of $38 \%$ of trees expected to be found infected was nonsignificant (Chi-square $=1.74,3$ d.f, $P=0.05$ ). This result indicated that differences as large as those observed in the proportion of trees found infected in the various health categories could be expected due to chance.
Categories 4 and 5 were combined for tabulation and calculations, because only two trees in category 5 were tested.

The presence of MLOs in velvet ash saplings indicated that young plants are at risk of infection and that some ash probably are becoming infected every year. We conclude that ash yellows is distributed throughout Zion Canyon and is endemic there in a large proportion of the velvet ash. We believe that the decline of velvet ash in Zion Canyon may result not from MLO infection alone but from an interaction of MLO infection, foliar damage by insects, and water shortage. The probable nature of the interaction is that trees infected with MLOs have subnormal vigor. Infected trees do not recover from drought stress or insect attack as fully as do comparable noninfected trees.

MLOs were not detected in singleleaf ash, although 27 of the 34 trees examined displayed dieback, and the remainder had thin crowns. The reaction of DAPI with nuclear DNA in phloem parenchyma cells of the 34 plants examined appeared normal. Therefore, we believe the DAPI test would have allowed detection of MLOs, had they been present in phloem sieve tubes. We conclude that singleleaf ash trees in Zion Canyon are free from MLOs.

It was not possible to examine singleleaf ash on sites occupied by diseased velvet ash, because, except for isolated individuals, the two species are not found growing together. Singleleaf ash colonizes more xeric sites than does velvet ash.

\section{$\downarrow \quad$ Continuing Studies}

The following lines of work have begun, but data are not yet available:

1. infection in plants other than ash in Zion Park;

2. Radial growth of velvet ash in relation to MLO infection;

3. Incidence of MLO infection as related to dieback and slow growth in velvet ash saplings;

4. Possible masked symptoms of ash yellows in a creekbed population of velvet ash.

5. Identification of the ash yellows MLOs in Zion Park by dot hybridizations with cloned biotinylated DNA probes; and 
6. Preparation of small ash trees for a chemotherapy experiment.

\section{$\downarrow$ Summary}

Velvet ash (Fraxinus velutina) trees in Zion Canyon, Zion National Park, are in declining health, and many exhibit severe dieback. A disease called ash yellows, which is caused by unnamed mycoplasmalike organisms (MLOs) was detected in declining velvet ash in Zion Park in 1988 and was suspected to cause or contribute to the decline. MLOs are obligately intracellular prokaryotic parasites of plants and certain insects. They typically cause slow growth and decline in woody plants.

Research on ash yellows in Zion Park began in May, 1990 with the following objectives:

1. Determine the extent of damage to the ash species in Zion Park, and map the distribution of ash yellows in the park.

2. Learn whether or not the MLOs in ash in Zion Park are closely related to those associated with ash yellows in Nevada and New York.

3. Determine the means and rate of spread of ash yellows and the rate at which the epidemic is progressing within the currently affected area.

4. Assess the possibilities for managing the disease.

The presence of ash yellows in velvet ash was confirmed by means of the DAPI fluorescence test, which is a standard test for detection of MLOs in plants. The disease was found to be distributed throughout Zion Canyon in $38 \%$ of the 174 trees examined. Because MLOs were found in saplings as well as large trees, and because some normalappearing trees were also found infected, we believe that new infections probably are occurring yearly. The effects of this disease alone on velvet ash are, as yet, obscure, because the affected ash population has also been subject to drought stress and damage by defoliating insects in recent years. Based on experience with ash yellows in the East, however, we hypothesize that MLO-infected ash are less vigorous than comparable noninfected trees and are less tolerant of drought stress and defoliation.

A search for declining velvet ash along highways in localities near Zion Park revealed no syndrome similar to that found in Zion Park.

Singleleaf ash, the only other ash species indigenous to Zion Park, was examined for MLO infection with negative results.

Additional lines of work are in progress, as indicated by the following titles:

Micoplasmal infection in plants other than ash in Zion Park

Radial growth of velvet ash in relation to MLO infection

Incidence of ash yellows as related to dieback and slow growth in velvet ash saplings

Possible masked symptoms of ash yellows in a creekbed population of velvet ash

Identification of the ash yellows MLOs in Zion Park by dot hybridizations with cloned biotinylated DNA probes

Preparation of small ash trees for a chemotherapy experiment.

Table 1. DAPI test scores in relation to health categories of velvet ash.

Health category

1. (Normal and vigorous)

2. (Thin canopy or slow growth)

3. (Thin canopy and some dieback)

4. (Dieback general or involving large limbs) plus

5. (Dead to near ground level)

Totals and average
Trees tested

(no.)

\section{DAPI-positive}

Number Percent

$\begin{array}{lrl}15 & 3 & 20 \\ 66 & 24 & 36 \\ 63 & 26 & 41 \\ 30 & 13 & 43 \\ 174 & 66 & 38\end{array}$

